\title{
1 Title: Estimating the effect of lipids on IGF axis and subsequent breast cancer risk
}

2 Short title: Lipids, IGFs and breast cancer risk

3 Vanessa $\mathrm{Y} \operatorname{Tan}^{1,2 \dagger}$, Caroline J Bull ${ }^{1,2 \dagger}$, Kalina M Biernacka ${ }^{3}$, Alexander Teumer ${ }^{4}$, Laura 4 Corbin $^{1,2}$, Tom Dudding ${ }^{1,12}$, Eleanor Sanderson ${ }^{1,2}$, Qibin $\mathrm{Qi}^{5}$, Robert C Kaplan ${ }^{5,6}$, Jerome I

5 Rotter $^{7}$, Nele Friedrich ${ }^{8}$, Uwe Völker ${ }^{9}$, Julia Mayerle ${ }^{10,11}$, Claire M Perks ${ }^{3}$, Jeff MP Holly ${ }^{3}$,

6 Nicholas J Timpson ${ }^{1,2}$

$7 \quad{ }^{\dagger}$ Joint first

$8 \quad{ }^{1}$ Medical Research Council (MRC) Integrative Epidemiology Unit, Population Health

9 Sciences, Bristol Medical School, University of Bristol, Bristol, United Kingdom.

$10{ }^{2}$ Population Health Sciences, Bristol Medical School, University of Bristol, Bristol, United 11 Kingdom.

$12{ }^{3}$ IGFs \& Metabolic Endocrinology Group, School of Translational Health Sciences, Learning \&

13 Research Building, Southmead Hospital, Bristol, United Kingdom.

$14{ }^{4}$ Institute for Community Medicine, University Medicine Greifswald, Greifswald, 17475, 15 Germany.

$16{ }^{5}$ Department of Epidemiology and Population Health, Albert Einstein College of Medicine, 17 Bronx, NY, 10461, USA.

$18{ }^{6}$ Division of Public Health Sciences, Fred Hutchinson Cancer Research Center, Seattle WA.

$19{ }^{7}$ The Institute for Translational Genomics and Population Sciences, Department of Pediatrics,

20 The Lundquist Institute for Biomedical Innovation at Harbor-UCLA Medical Center, Torrance,

21 CA USA

$22{ }^{8}$ Institute of Clinical Chemistry and Laboratory Medicine, University Medicine Greifswald,

23 Greifswald, 17475, Germany.

$24{ }^{9}$ Interfaculty Institute for Genetics and Functional Genomics, University Medicine Greifswald,

25 Greifswald, 17475, Germany.

$26{ }^{10}$ Department of Medicine A, University Medicine Greifswald, Greifswald, 17475, Germany.

$27{ }^{11}$ Department of Medicine II, University Hospital, LMU Munich, Munich, 80539, Germany.

$28{ }^{12}$ Bristol Dental School, University of Bristol, Bristol, United Kingdom. 
medRxiv preprint doi: https://doi.org/10.1101/2020.06.04.20122630; this version posted June 7, 2020. The copyright holder for this preprint

(which was not certified by peer review) is the author/funder, who has granted medRxiv a license to display the preprint in perpetuity.

All rights reserved. No reuse allowed without permission.

30 Corresponding author: Professor Nicholas J. Timpson, Address: MRC Integrative

31 Epidemiology Unit, University of Bristol, Oakfield House, Oakfield Grove, Bristol, BS8 2BN,

32 email: N.J.Timpson@bristol.ac.uk

33

34

Abstract

35 Circulating lipids have been associated with breast cancer (BCa). This association may, in 36 part, be due to an effect of lipids on insulin-like growth factors (IGFs), which have been 37 reliably associated with $\mathrm{BCa}$. In two-sample Mendelian randomization (MR) analyses, we 38 found that low density lipoprotein (LDL-C) was associated with IGFBP-3 (beta:0.08 SD; $3995 \% \mathrm{Cl}: 0.02,0.15 ; p=0.01$, per SD increase in LDL-C) and IGFBP-3 was associated with 40 postmenopausal BCa (OR:1.09; 95\%Cl:1.00,1.19; $p=0.05$, per SD increase in IGFBP-3). We 41 also found that triglycerides were associated with IGF-I (beta:-0.13SD; 95\%Cl:-0.22,-0.03, per

42 SD increase in triglycerides) and that IGF-I was associated with overall $\mathrm{BCa}$ 43 (OR:1.10;95\%Cl:1.02,1.18, per SD increase in IGF-I). Taken together, these results suggest 44 that IGFBP-3 may be a potential causal step between LDL-C and postmenopausal BCa and 45 IGF-I a potential causal for triglycerides. Our two-step MR results build on evidence linking circulating lipids and IGFs with BCa, however, multivariable MR analyses are currently unable to support this relationship due to weak instruments.

48

Key words: Breast cancer, Mendelian randomization, Insulin-like growth factors, lipids

50

Main text words:4281; Abstract:157; References:61; Tables \& Figures: 10; 
medRxiv preprint doi: https://doi.org/10.1101/2020.06.04.20122630; this version posted June 7, 2020. The copyright holder for this preprint

(which was not certified by peer review) is the author/funder, who has granted medRxiv a license to display the preprint in perpetuity.

All rights reserved. No reuse allowed without permission.

\section{Introduction}

Breast cancer $(\mathrm{BCa})$ is one of the leading causes of cancer-related deaths worldwide ${ }^{1,2}$. Circulating lipids including low density lipoprotein (LDL-C), high density lipoprotein (HDL-C) and triglycerides have been associated with known risk factors for BCa such as obesity ${ }^{3,4}$. However, evidence from observational studies investigating the relationship between lipid profile and $\mathrm{BCa}$ risk has been conflicting ${ }^{5,6}$. Statins competitively inhibit 3-hydroxy-3methylglutaryl-coenzyme A (HMGCR) to reduce circulating LDL-C and are commonly prescribed for the prevention and treatment of cardiovascular disease, but have also been hypothesised to have anti-cancer effects ${ }^{7}$. Most observational studies have found no evidence of an association between statin use and $\mathrm{BCa}$ risk ${ }^{8}$. However, reverse causation, confounding and other biases may limit the interpretation of these observational findings. The associations, estimated from these observational studies, between statin therapy and breast cancer are particularly problematic, due to selection and so called immortal time biases ${ }^{9}$.

Mendelian randomization (MR) is an analytical approach where genetic variants reliably associated with risk factors of interest are used as "proxy" measures to investigate whether the effect of an exposure on an outcome is likely to be causal ${ }^{10}$. A recent MR study reported a positive association between LDL-C and HDL-C with overall or estrogen receptor (ER)positive $\mathrm{BCa}$ risk $^{11}$. It is becoming increasingly feasible to study drug effects in a MR framework using genetic variants located in the genes of the drug's protein targets ${ }^{12}$. Genetic variants in $H M G C R$, associated with increased LDL-C levels, have been found to associate with increased overall and ER-positive BCa risk ${ }^{13,14}$. The mechanism by which statins protect against BCa and whether the effect differs by menopausal status remains to be elucidated.

Several randomised control trials have suggested that statin use is associated with alterations in circulating levels of insulin-like growth factors (IGFs), suggesting that perturbation of circulating lipids can alter levels of IGF axis traits ${ }^{15-17}$. The IGF axis includes IGF-I, IGF-II and six IGF binding proteins (IGFBPs), which are important for cancer initiation and progression through the regulation of cell growth, metabolism and survival ${ }^{18-21}$. A recent meta-analysis of individual data from observational studies found evidence that IGF-I was associated with 
increased $\mathrm{BCa}$ risk in both pre and postmenopausal women while IGFBP-3 was only associated with increased $\mathrm{BCa}$ risk in postmenopausal women ${ }^{22}$. However, it is unclear if a causal relationship between circulating IGFs and BCa exists, and whether estrogen receptor or menopausal status is important.

The role of the IGF axis in metabolic regulation is well-established ${ }^{23-25}$. Intervention studies in patients with growth hormone disorders support a link between IGF and lipid biology ${ }^{26-28}$. Population-based studies examining the relationship between circulating IGFs and lipid profile have yielded conflicting results ${ }^{29-31}$, however, these studies may be limited by their crosssectional design. Hence, the direction of association and whether causation exists between circulating lipids and IGFs is still unclear. Given previous evidence implicating lipids and IGFs as potential modifiable risk factors for cancer $^{32-34}$, there is motivation to assess the relationship between IGFs and lipids to investigate the mechanisms underlying BCa risk.

We aimed to investigate circulating IGFs as potential intermediates between lipid profile and $\mathrm{BCa}$ risk. We set out to examine the association between circulating lipid traits (LDL-C, HDLC and TG), IGFs (IGF-I and IGFBP-3) and BCa (stratified by menopausal and ER status) using a two-step MR study design ${ }^{35}$.

\section{Materials and Methods}

\section{Study design and data sources}

To estimate the causal relationship between lipids and BCa using MR Figure 1,(i)), we obtained summary statistics from: i) a lipid GWAS conducted by the Global Lipids Genetic Consortium (GLGC, $n=188,577)^{36}$; ii) a BCa risk GWAS (overall $(n=228,951)$ and stratified by estrogen receptor status ( $n=69,501$ for ER positive BCa and $n=21,468$ for ER negative $\mathrm{BCa}$ ) conducted by the Breast Cancer Association Consortium (BCAC, ${ }^{37}$; and iii) a BCa risk GWAS (overall $(n=230,954)$ and stratified by menopausal status (premenopausal BCa, $\mathrm{n}=59,124$ for premenopausal BCa and $\mathrm{n}=112,245$ for postmenopausal $\mathrm{BCa}$ ) conducted in UK Biobank (see Supplementary methods). 
119 To investigate the observational relationship between lipids and IGFs (Figure 1, (ii)), we used

120 individual-level data $(n=3,812)$ from the Study of Health in Pomerania (SHIP) where

121 circulating lipids and IGFs were measured (these data are described in detail in the

122 Supplementary methods).

123

124 To estimate the causal relationship between lipids and IGF-I or IGFBP-3 using MR (Figure 1,

125 (iii)), we obtained summary statistics from: i) the lipid GWAS conducted by the $\mathrm{GLGC}^{36}$, as

126 described above and ii) the IGF GWAS conducted by the "IGF working group" of the

127 CHARGE consortium $(n=30,884)^{38}$ (see Supplementary methods).

128

129 To estimate the causal relationship between circulating IGFs and BCa (Figure 1,(iv)), we

130 obtained summary statistics from: i) the IGF GWAS(29); ii) the BCa risk GWAS conducted by

$131 \mathrm{BCAC}^{37}$ (overall and stratified by ER status); and iii) the BCa risk GWAS conducted in UKBB

132 (overall and stratified by menopausal status)(see Supplementary methods).

133

134 To assess the potential causal effect of changes in LDL-C levels due to lipid lowering drugs

135 such as statins on BCa and IGF levels (Figure 1,(v)), we constructed a genetic instrument to

136 proxy statin treatment which comprised of 5 SNPs (rs12916, rs10515198, rs12173076, 137 rs3857388, and rs7711235) within 100kb from the gene region for HMGCR and in low linkage 138 disequilibrium $\left(r^{2}<0.20\right)^{39}$. These SNPs were robustly associated $\left(p<5 \times 10^{-8}\right)$ with LDL-C in the 139 lipid GWAS conducted by GLGC ${ }^{36}$. We obtained summary statistics for the genetic variants in 140 HMGCR from: i) the lipid GWAS [29]; ii) the IGF GWAS(29); iii) the BCa risk GWAS 141 conducted by $\mathrm{BCAC}^{37}$; and iv) the BCa risk GWAS conducted in UKBB (see Supplementary 142 methods).

143

144 Genetic instruments for MR analyses

145 The GLGC identified 185 SNPs $\left(r^{2}<0.2\right)$ associated with at least HDL-C, LDL-C or TG $146\left(p<5 \times 10^{-8}\right)^{36}$ (see Supplementary Table 1 for list of SNPs). Due to the complex overlapping 147 nature of the lipid traits, genetic variants are commonly associated with more than one lipid 148 trait. To go some way to disentangling the roles of LDL-C, HDL-C and TG, we used 
149 multivariable MR which was developed to estimate the causal effect of various correlated risk 150 factors when conditioned on one another in a single model ${ }^{40,41}$ (see Supplementary 151 methods for more details). For the multivariable MR analyses (Figure 1, (i)), all 185 SNPs 152 were included in the model. Univariable MR methods included SNPs associated with a given 153 lipid trait at a genome-wide level of significance $\left(p<5 \times 10^{-8}, 76\right.$ for LDL-C, 86 for HDL-C or 51 154 for TG). Sex-specific GWAS results were not available for lipid traits.

155

156 For the IGF MR analyses (Figure 1, (iii)\&(iv)), we used 7 and 4 independent SNPs $\left(r^{2}<0.01\right.$ ), 157 associated $\left(\mathrm{p}<5 \times 10^{-8}\right)$ with IGF-I and IGFBP-3, respectively, as identified by a IGFs GWAS 158 (see Supplementary Table 2 for list of SNPs) ${ }^{38}$. IGF-II and IGFBP-2 were not investigated as 159 GWAS summary results are not currently available for these traits. For IGFBP-3, marked 160 differences in effect sizes by sex were found for 2 variants (with stronger associations in 161 women). As differences in effect size could potentially bias MR estimates ${ }^{42}$, analyses 162 estimating the causal relationship between IGF-I or IGFBP-3 and BCa were conducted using female-specific effect estimates for IGF-I and IGFBP-3.

164

Statistical analyses

166 Multivariable MR was used to estimate the effect of LDL-C, HDL-C and TG on the odds of 167 BCa when conditioned on one another (Figure 1, (i)). As there were likely to be differences 168 between the causal estimates between BCAC and UKBB, a random-effects meta-analysis 169 was used to combine MR estimates using BCAC and UKBB summary statistics using the 170 'metan' package in Stata. Analyses stratified by ER status (in BCAC) and menopausal status 171 (in UKBB) were also conducted.

173 Observational associations between lipids and IGF-I or IGFBP-3 were assessed using linear 174 regression (Figure 1, (ii)). Fully adjusted models included age, sex, smoking status, body 175 mass index (BMI) and diabetes status. Associations of lipids and IGFs with potential confounders were estimated using linear regression. 
178 Bidirectional MR was performed to assess the causal effect of lipids on IGF-I and IGFBP-3

179 and vice versa (Figure 1, (iii)). SNP-exposure and SNP-outcome associations were combined

180 using the inverse variance weighted (IVW) method ${ }^{43}$. MR-Egger $^{44}$, weighted median ${ }^{45}$ and

181 multivariable $\mathrm{MR}^{40,41}$ were performed as sensitivity analyses.

182

183 To assess the causal effect of IGFs on BCa, SNP-exposure (SNP-IGF) and SNP-outcome

184 (SNP-BCa) associations were combined using inverse variance weighting (Figure 1, (iv)) ${ }^{43}$.

185 MR-Egger and weighted median were not conducted as these lack power for instruments with

186 a small number of SNPs ${ }^{46}$. SNPs associated with IGF-I are also associated with other

187 components of the IGF pathway ${ }^{38}$. To attempt to account for the overlapping associations for

188 these SNPs, we employed multivariable MR by regression of the SNP-BCa estimates on

189 SNP-IGF-I and SNP-IGFBP-3 estimates in a multivariable weighted regression model. A

190 random-effects meta-analysis was used to combine BCAC and UKBB estimates. Analyses

191 stratified by ER status (in BCAC) and menopausal status (in UKBB) were also conducted.

192

193 Multivariable $\mathrm{MR}^{47}$ was conducted as an extension of the IVW method to test the hypothesis

194 that circulating IGF-I or IGFBP3 act as intermediate factors in any association between lipid

195 profile and $\mathrm{BCa}$, identified by the analyses outlined above (Figure 1, (i-iv)). Two-sample

196 Conditional F-statistics ${ }^{48}$ were estimated to predict instrument strength in the multivariable

197 model.

198

199 To estimate the causal relationship between statin use and BCa or IGF levels, we used a

200 random-effect linear regression model weighted by the inverse variance of the SNP-BCa

201 associations. The genetic correlation between the 5 SNPs in HMGCR was incorporated into

202 the MR model using the weighted generalized linear regression method implemented in the

203 'MendelianRandomization' R package ${ }^{49,50}$.

204

205 All MR analyses were performed using the MR-Base "TwoSampleMR" package ${ }^{51}$. All other

206 statistical analyses were performed using Stata version 14 (StataCorp, College Station,

207 Texas, USA) or $\mathrm{R}$ version 3.2.4. 
medRxiv preprint doi: https://doi.org/10.1101/2020.06.04.20122630; this version posted June 7, 2020. The copyright holder for this preprint (which was not certified by peer review) is the author/funder, who has granted medRxiv a license to display the preprint in perpetuity.

All rights reserved. No reuse allowed without permission.

\section{Results}

211 Re-assessing the causal relationship between circulating lipids with breast cancer

212 The relationship between circulating lipids and $\mathrm{BCa}$ in $\mathrm{BCAC}$ and UKBB was estimated using 213 multivariable MR. In BCAC, the odds ratio (OR) for overall $\mathrm{BCa}$ per SD increase in LDL-C, 214 HDL-C and TG was $1.06(95 \% \mathrm{Cl} 1.01,1.12 ; p=0.02), 1.07(95 \% \mathrm{Cl} 1.01,1.14 ; p=0.03)$ and $2150.93(95 \% \mathrm{Cl}: 0.86,1.00 ; p=0.06)$, respectively (Figure 2). In UKBB, MR estimates of the 216 association between LDL-C, HDL-C, and TG and BCa were consistent with results in BCAC 217 (Figure 2). In a meta-analysis of BCAC and UKBB data, the OR for overall BCa per SD 218 increase in LDL-C, HDL-C and TG was $1.07(95 \% \mathrm{Cl} 1.02,1.12 ; p=0.01), 1.06(95 \% \mathrm{Cl} 1.01$, $2191.10 ; p=0.01)$ and $0.94(95 \% \mathrm{Cl} 0.89,1.00 ; p=0.05)$, respectively (Figure 2).

220

221 Using data from BCAC, we extended this to the investigation of the relationship between 222 circulating lipids and BCa, stratified by ER status. The OR for ER-positive BCa per SD 223 increase in LDL-C, HDL-C and TG was $1.06(95 \% \mathrm{Cl} 0.99,1.12 ; p=0.07), 1.08(95 \% \mathrm{Cl} 1.01$, $2241.15 ; p=0.04)$ and $0.93(95 \% \mathrm{Cl} 0.86,1.02 ; p=0.11)$, respectively. The OR for ER-negative 225 BCa per SD increase in LDL-C, HDL-C and TG was $1.05(95 \% \mathrm{Cl} 0.98,1.13 ; p=0.16), 1.08$ $226(95 \% \mathrm{Cl} 0.99,1.18 ; p=0.09)$ and $0.92(95 \% \mathrm{Cl} 0.83,1.02 ; p=0.11)$, respectively (Table 1).

Using data from UKBB, we investigated the relationship between circulating lipids and $\mathrm{BCa}$,

229 stratified by menopausal status. We found evidence that LDL-C was associated with 230 increased odds of postmenopausal BCa (OR 1.14, 95\% Cl 1.04, 1.25; $p=0.004)$, but there was 231 weak evidence for premenopausal BCa (OR 1.07, 95\% CI 0.91, 1.26; $p=0.42)$. There was little 232 evidence to suggest that HDL-C or TG associated with either premenopausal or 233 postmenopausal BCa (Table 1).

235 Observational relationship between circulating lipids and levels of IGF-I and IGFBP-3 in the 236 SHIP study 
medRxiv preprint doi: https://doi.org/10.1101/2020.06.04.20122630; this version posted June 7, 2020. The copyright holder for this preprint (which was not certified by peer review) is the author/funder, who has granted medRxiv a license to display the preprint in perpetuity.

All rights reserved. No reuse allowed without permission.

237 Study characteristics of the SHIP study are shown in Supplementary Table 3. The mean

238 (SD) IGF-I and IGFBP-3 levels were 142.1 (57.6) $\mathrm{ng} / \mathrm{ml}$ and 1884.9 (503.5) $\mathrm{ng} / \mathrm{ml}$,

239 respectively. The mean (SD) LDL-C, HDL-C and TG levels were 3.57 (1.16) $\mathrm{mmol} / \mathrm{l}, 1.45$

240 (0.44) $\mathrm{mmol} / \mathrm{l}$ and 1.82 (1.30) $\mathrm{mmol} / \mathrm{l}$, respectively. For IGF-I, a SD unit increase in LDL-C,

241 HDL-C and TG was associated with a $-0.11\left(95 \% \mathrm{Cl}-0.14,-0.08 ; p=2.27 \times 10^{-12}\right), 0.02(95 \% \mathrm{Cl}$ -

$2420.01,0.05 ; p=0.29)$ and $-0.16\left(95 \% \mathrm{Cl}-0.19,-0.13 ; p=2.26 \times 10^{-22}\right)$ SD unit change in IGF-I

243 levels, respectively. For IGFBP-3, a SD unit increase in LDL-C, HDL-C and TG was

244 associated with a $-0.01(95 \% \mathrm{Cl}-0.04,0.02 ; p=0.47), 0.06\left(95 \% \mathrm{Cl} 0.03,0.10 ; p=7.01 \times 10^{-5}\right)$

245 and $0.03(95 \% \mathrm{Cl}-0.003,0.06 ; p=0.08)$ SD unit change in IGFBP-3 levels, respectively.

246 Circulating lipids and IGF traits were associated with potential confounders of a lipid- or IGF-

247 BCa relationship, including age, sex, smoking status, diabetes status and body mass index

248 (Supplementary Table 4). In the fully adjusted model, a SD unit increase in LDL-C, HDL-C

249 and TG was associated with a $0.03(95 \% \mathrm{Cl} 0.004,0.06 ; p=0.03),-0.05(95 \% \mathrm{Cl}-0.08,-0.02$;

$250 p=0.001)$ and $-0.06\left(95 \% \mathrm{Cl}-0.09,-0.04 ; p=1.5 \times 10^{-5}\right)$ SD unit change in IGF-I levels,

251 respectively. For IGFBP-3, a SD unit increase in LDL-C, HDL-C and TG was associated with

252 a $0.08\left(95 \% \mathrm{Cl} 0.05,0.11 ; p=1.12 \times 10^{-7}\right),-0.02(95 \% \mathrm{Cl}-0.05,0.02 ; p=0.30)$ and $0.13(95 \% \mathrm{Cl}$

$2530.10,0.16 ; p=2.69 \times 10^{-15}$ ) SD unit change in IGFBP-3 levels, respectively (Table 2).

254

255 Estimating the causal relationship between circulating lipids and IGFs

256 There was little evidence to suggest that LDL-C or HDL-C alter IGF-I levels. The MR estimate

257 of the causal relationship between TG and IGF-I was -0.13 SD units $(95 \% \mathrm{Cl}-0.22,-0.03$;

$258 p=0.01)$ per SD unit increase in TG. Estimates obtained using MR-Egger regression, 259 weighted median and multivariable MR methods were of similar magnitude (Table 3). There

260 was little evidence for directional pleiotropy using Egger regression (Intercept: 0.007; se:

2610.004 ; directionality $p=0.11)$. In the reverse direction, there was little evidence to suggest that

262 IGF-I altered circulating LDL-C, HDL-C or TG (Table 4).

263

264 The MR estimate of the causal relationship between LDL-C and IGFBP-3 was 0.08 SD units

$265(95 \% \mathrm{Cl} 0.02,0.15 ; p=0.01)$ per SD unit increase in LDL. There was little evidence for an 266 association between HDL-C and IGFBP-3 (Table 3). The IVW estimate of the causal 
medRxiv preprint doi: https://doi.org/10.1101/2020.06.04.20122630; this version posted June 7, 2020. The copyright holder for this preprint (which was not certified by peer review) is the author/funder, who has granted medRxiv a license to display the preprint in perpetuity.

All rights reserved. No reuse allowed without permission.

267 relationship between TG and IGFBP-3 was 0.10 SD units $(95 \% \mathrm{Cl} 0.01,0.19 ; p=0.03)$ per SD

268 unit increase in TG. Estimates obtained using MR-Egger regression, weighted median and

269 multivariable MR methods were consistent with the IVW analyses for LDL-C and TG (Table

270 3). In the reverse direction, there was minimal evidence to suggest that IGFBP-3 altered

271 circulating LDL-C, HDL-C or TG (Table 4).

272

273 Estimating the causal relationship between circulating IGFs and breast cancer

274 Using data from BCAC, the OR for overall BCa per SD increase in IGF-I and IGFBP-3 (using

275 the IVW method) was $1.10(95 \% \mathrm{Cl} 1.01,1.20 ; p=0.02)$ and $1.00(95 \% \mathrm{Cl} 0.96,1.03 ; p=0.95)$,

276 respectively. Estimates from multivariable MR analyses were consistent with the IVW

277 analyses unadjusted for IGF-I (OR 1.12, 95\% CI 1.03, 1.20; $p=0.01)$ and IGFBP-3 (OR 0.98,

$27895 \% \mathrm{Cl} 0.95,1.02 ; p=0.40)$. In UKBB, estimates for the effect of IGF-I on BCa were

279 comparable. For IGFBP-3, the OR for overall BCa per SD increase in IGFBP-3 was 1.08

$280(95 \% \mathrm{Cl} 1.01,1.15 ; p=0.03)$ and $1.08(95 \% \mathrm{Cl} 1.01,1.16 ; p=0.02)$, estimated by IVW and

281 multivariable MR, respectively (Table 5). When results from BCAC and UKBB were meta-

282 analysed, the OR for overall BCa for IGF-I and IGFBP-3 was $1.10(95 \% \mathrm{Cl} 1.02,1.18 ; p=0.01)$

283 and $1.02(95 \% \mathrm{Cl} 0.99,1.06 ; p=0.21)$, respectively, from IVW analyses (Figure 3).

284

285 We also investigated the relationship between IGF traits and BCa by ER-status. The OR for

286 ER-positive BCa per SD increase in IGF-I and IGFBP-3 (using the IVW method) was 1.10

287 (95\%Cl: $0.99,1.20 ; p=0.06)$ and $1.00(95 \% \mathrm{Cl}: 0.96,1.04 ; p=0.94)$, respectively. The OR for

288 ER-negative BCa per SD increase in IGF-I and IGFBP-3 (using the IVW method) was 1.05

289 (95\%Cl: $0.90,1.23 ; p=0.53)$ and $0.98(95 \% \mathrm{Cl}: 0.92,1.04 ; p=0.43)$, respectively. For IGF-I and

290 IGFBP-3, multivariable MR and IVW estimates were consistent for both ER-positive and ER-

291 negative BCa (Table 5).

292

293 Using data from UKBB, we investigated the relationship between IGF traits and BCa stratified

294 by menopausal status. The OR for postmenopausal BCa per SD increase in IGF-I and 295 IGFBP-3 (using the IVW method) was $0.97(95 \% \mathrm{Cl} 0.78,1.20 ; p=0.77)$ and $1.09(95 \% \mathrm{Cl}$ $2961.00,1.19 ; p=0.05)$, respectively. The OR for premenopausal BCa per SD increase in IGF-I 
medRxiv preprint doi: https://doi.org/10.1101/2020.06.04.20122630; this version posted June 7, 2020. The copyright holder for this preprint (which was not certified by peer review) is the author/funder, who has granted medRxiv a license to display the preprint in perpetuity.

All rights reserved. No reuse allowed without permission.

297 and IGFBP-3 (using the IVW method) was $1.19(95 \% \mathrm{Cl} 0.76,1.87 ; p=0.46)$ and $0.93(95 \% \mathrm{Cl}$

$2980.77,1.12 ; p=0.45$ ), respectively. For IGF-I and IGFBP-3, multivariable MR and IVW

299 estimates were consistent for both pre- and post-menopausal BCa (Table 5).

300 Multivariable MR analyses to estimate whether IGFs are on the causal pathway between

$301 \quad$ lipids and BCa

302 As a sensitivity analysis, MVMR analyses were conducted to investigate if the effect of TG on

303 overall BCa was attenuated following adjustment for IGF-I. Using data from BCAC, the

304 multivariable MR OR for overall BCa per SD increase in TG, conditioned on IGF-I, was 0.92

$305(95 \% \mathrm{Cl} 0.86,1.10 ; p=0.03)$. In UKBB, estimates for the effect of TG on overall BCa after

306 conditioning on IGF-I were comparable. When results from BCAC and UKBB were meta-

307 analysed, the multivariable MR OR for overall BCa per SD increase in TG, conditioned on

308 IGF-I, was $0.93(95 \% \mathrm{Cl} 0.88,0.99 ; p=0.03)$, which did not differ in size or magnitude when

309 compared to the IGF-I unadjusted model (OR 0.94; 95\%Cl 0.89, 1.00; $p=0.05)$ (Table 6).

310

311 Using data from UKBB, MVMR analyses were conducted to investigate if the effect of LDL-C 312 on post-menopausal BCa was attenuated following adjustment for IGFBP-3. The multivariable

313 OR for postmenopausal BCa per SD increase in LDL-C, conditioned on IGFBP-3 was 1.11

$314(95 \% \mathrm{Cl} 1.02,1.20 ; p=0.02)$, which did not differ by size and direction of effect when 315 compared to the IGFBP-3 unadjusted model (OR 1.13; 95\%Cl 1.04, 1.25; $p=0.004)$ (Table 6).

317 Estimating the causal relationship between LDL-C raising genetic variants in HMGCR with

318 BCa and IGF levels.

319 LDL-C raising variants in HMGCR (which simulate activation of HMGCR) were associated 320 with increased odds of $\mathrm{BCa}$ in $\mathrm{BCAC}$ (OR 1.20,95\%Cl 1.02, 1.40; $p=0.03$ ). In UKBB, the 321 estimated causal effect of LDL-C raising variants in HMGCR was consistent but less precise 322 (OR 1.34, 95\% $\mathrm{Cl} 0.90,2.02 ; p=0.15$ ). The meta-analysed OR for overall $\mathrm{BCa}$ in $\mathrm{BCAC}$ and 323 UKBB was $1.22(95 \% \mathrm{Cl} 1.04,1.43 ; p=0.01)$ (Table 7). Using data from BCAC, LDL-C raising 324 variants in HMGCR were associated with increased odds of ER-positive BCa (OR 1.21, $32595 \% \mathrm{Cl} 1.00,1.47 ; p=0.05$ ) but not ER negative $\mathrm{BCa}$ (OR 1.20, 95\% Cl 0.90, 1.60; $p=0.23$ ). 
medRxiv preprint doi: https://doi.org/10.1101/2020.06.04.20122630; this version posted June 7, 2020. The copyright holder for this preprint

(which was not certified by peer review) is the author/funder, who has granted medRxiv a license to display the preprint in perpetuity.

All rights reserved. No reuse allowed without permission.

327 Using data from UKBB, LDL-C raising variants in HMGCR were associated with increased

328 odds of postmenopausal BCa (OR 1.63, 95\% Cl 1.06, 2.49; $p=0.03)$, but not premenopausal

329 BCa (OR 1.47, 95\% Cl 0.57, 3.75; $p=0.42$ ) (Table 7). There was weak evidence that statins

330 could reduce IGF-I (beta: $0.02,95 \% \mathrm{Cl}-0.02,0.43, p=0.07$ ). There was little evidence that

331 genetic variants in HMGCR were associated with IGFBP-3 (Table 7).

332

\section{Discussion}

334 In this study, we aimed to estimate the effect of circulating lipids and IGF traits on BCa and to

335 investigate the role of circulating IGFs in the association between circulating lipids and BCa.

336 We used complementary approaches to investigate circulating IGFs as causal intermediates

337 between lipids and BCa. We found that TG was inversely associated with IGF-I and overall

338 BCa and that IGF-I is positively associated with overall BCa. We also found that LDL-C was

339 positively associated with IGFBP-3 and postmenopausal BCa and that IGFBP-3 is positively

340 associated with postmenopausal BCa. Two-step MR results supported a hypothetical

341 pathway between TG, IGF-I and overall BCa and also between LDL-C, IGFBP-3 and

342 postmenopausal BCa.

343

344 A recent two-sample MR study assessed the relationship between circulating lipids and BCa

345 in $\mathrm{BCAC}^{11}$. In an attempt to account for pleiotropic effects, the authors conducted sensitivity

346 analyses by excluding pleiotropic variants. However, manual pruning of SNPs that are

347 considered pleiotropic may result in an instrument that does not account for the underlying

348 genetic architecture of the trait, resulting in findings that can be challenging to interpret ${ }^{52}$.

349 Given that genetic variants included in the model are associated with multiple lipid fractions,

350 the MR assumption that all genetic variants are valid instruments (i.e. not pleiotropic) is

351 unlikely to hold. In this investigation, we have employed a multivariable MR approach, which

352 allows genetic variants to have pleiotropic effects on other variables included in the model

353 and jointly estimates the independent causal effect of each risk factor on the outcome. Our

354 multivariable MR analysis found that TG is negatively associated with overall $\mathrm{BCa}$, which was

355 not observed in previous MR studies ${ }^{11,14}$. Care is needed in interpretation however as whilst

356 these may reflect real differences, they could also be because of differences in analytical 
357 complexities. For example, MVMR model estimates the direct effect of each lipid conditional

358 on the other lipid traits which differ from the total effect of the lipids as estimated by

359 univariable MR analyses in the absence of pleiotropy.

360

361 Epidemiological evidence supports a relationship between lipids and IGFs ${ }^{15-17}$. In the context

362 of this relationship, we set out to assess the relationship between circulating lipids and IGFs

363 using a combination of observational and MR methods. Results from observational analyses

364 and MR analyses highlight that TG decreases IGF-I levels and that TG and LDL-C increases

365 IGFBP-3 levels. There was minimal evidence to suggest that circulating IGFs causally affect

366 lipid levels, although this finding may be limited by the availability of robust genetic

367 instruments for individual IGF traits ${ }^{53}$.

368

369 A meta-analysis of 17 studies and a case-control study showed that circulating IGF-I 370 increases odds of ER-positive BCa in pre- and postmenopausal women but not odds of ER371 negative $\mathrm{BCa}^{22,54}$. This finding is concordant with results of our study, suggesting that 372 circulating IGF-I increases overall BCa, likely driven by ER-positive BCa. Our MR results 373 suggest that circulating IGF-I is more influential in ER-positive BCa. However, preclinical 374 evidence suggests that IGF signalling is mitogenic for both ER-positive and ER-negative $375 \mathrm{BCa}^{55}$. As we have used genetic variants that predict circulating levels of IGF-I, we cannot 376 rule out important aspects of tissue-specific regulation which may contribute to BCa.

378 Menopause causes substantial disturbances to lipid metabolism ${ }^{56}$. Observational evidence 379 suggests that the association between lipids or IGFs and BCa depends on menopausal 380 status ${ }^{5,22}$. Using data from UKBB, our MR results suggest that circulating LDL-C is more 381 influential in postmenopausal BCa compared to premenopausal BCa. In contrast to previous 382 studies ${ }^{57-60}$, the association between HDL-C and BCa did not differ by menopausal status in 383 our analysis. IGFBP-3 appeared to be more influential in post-menopausal BCa, consistent 384 with findings from a meta-analysis of observational studies ${ }^{22}$. However, confidence intervals 385 were overlapping for both LDL-C and IGFBP-3 estimates in premenopausal and postmenopausal $\mathrm{BCa}$ analyses and the difference could be due to low statistical power in 
medRxiv preprint doi: https://doi.org/10.1101/2020.06.04.20122630; this version posted June 7, 2020. The copyright holder for this preprint

(which was not certified by peer review) is the author/funder, who has granted medRxiv a license to display the preprint in perpetuity.

All rights reserved. No reuse allowed without permission.

387 subgroup analyses, in particular the small number of cases in the premenopausal analysis ( $\mathrm{n}$

$388=1,781)$.

389

390

Our two-step MR results suggested a pathway between TG, IGF-I and overall BCa and a

391 pathway between LDL-C, IGFBP-3 and postmenopausal BCa. However, multivariable MR

392 analyses, wherein either IGF-I or IGFBP-3 were included as a covariate in the model, did not

393 attenuate the associations between TG and BCa or the associations between LDL-C and 394 postmenopausal BCa. This is counter to our interpretation of results, however our main 395 concern in this sensitivity analysis relates to instrument strength and the power of this 396 analysis. Instrument strength in a MVMR model can be assessed using a conditional $\mathrm{F}$ 397 statistic that summarises the relationship between genetic instruments and each exposure 398 conditional on the other exposures included in the MVMR model ${ }^{48}$. We assessed the 399 instrument strength in the multivariable MR models and found that the conditional F statistics 400 for IGF-I and IGFBP-3 were low (Table 6). In addition, assessment of the Q-statistic for 401 heterogeneity found evidence of potential pleiotropy in the MVMR model (Table 6), however, 402 this could be due to presence of conditionally weak instruments for the IGF measures.

403

404 Given that our study found evidence that LDL-C increases both BCa and IGFBP-3 levels, it 405 was appropriate to assess how statins (the most commonly prescribed LDL-lowering therapy) 406 impact BCa and IGFBP-3 levels using LDL-C raising genetic variants in HMGCR. Increased 407 LDL-C as proxied by genetic variants in HMGCR was associated with increased overall BCa, 408 consistent with results from a previous MR study ${ }^{13}$. In our analysis the effect estimate for 409 overall BCa using the LDL-C raising genetic variants in HMGCR was larger than the effect 410 estimate using the 185 SNP genome-wide LDL-C score. It seems likely that the difference in 411 the results could reflect properties of the instruments employed. The larger number of genetic 412 variants used to proxy LDL-C levels could capture pathways beyond HMGCR, therefore 413 pleiotropy could influence the effect estimate. As the 5 SNPs in the HMGCR used in the statin 414 analysis are weakly correlated, the multiplicity of associations due to LD between SNPS could 415 bias the MR results ${ }^{61}$. However, we attempted to account for the LD between the SNPs in the 416 HMGCR instrument in our MR analyses by accounting for these ${ }^{49,50}$. Differences in the results 
medRxiv preprint doi: https://doi.org/10.1101/2020.06.04.20122630; this version posted June 7, 2020. The copyright holder for this preprint (which was not certified by peer review) is the author/funder, who has granted medRxiv a license to display the preprint in perpetuity.

All rights reserved. No reuse allowed without permission.

417 using the HMGCR score and 185 SNP genome-wide LDL-C score could also be due to off-

418 target effects of statins (i.e. not via LDL-C). For example, a recent study by Kar et $\mathrm{al}^{13}$

419 suggested that BMI, rather than LDL-C, could be the true underlying mechanism responsible

420 for the protective association between genetic inhibition of HMGCR and $\mathrm{BCa}$.

421

422

Randomised control trials have shown that statin use results in altered levels of IGF-I and

423 IGFBP- $3^{15-17}$. Our study found weak evidence of an association between genetic variants in

$424 H M G C R$ and IGF-I levels and minimal evidence of an association with IGFBP-3 levels. Failure

425 to detect an association between statins an IGFBP3 may be due to the relatively small size of

426 the IGF GWAS.

427

428 Conclusion

429 This study employed complementary observational and MR analyses to confirm that LDL-C

430 and HDL-C are positively associated with overall BCa and that TG is negatively associated

431 with overall BCa. Our study found that TG is negatively associated with IGF-I and that IGF-I is

432 positively associated with overall $\mathrm{BCa}$, consistent with the TG-BCa association. We also

433 found that LDL-C is positively associated with IGFBP-3 and that IGFBP-3 is positively

434 associated with postmenopausal $\mathrm{BCa}$, consistent with the LDL-C-postmenopausal BCa

435 association. Our two-step MR results build on evidence linking circulating lipids and IGFs with

$436 \mathrm{BCa}$, however, multivariable MR analyses are currently unable to support this relationship due

437 to presence of conditionally weak instruments for the IGF measures.

438

\section{Funding}

440 This work was specifically supported by the Medical Research Council (MRC) Integrative

441 Epidemiology Unit (IEU) (MC_UU_12013/3) and by a Cancer Research UK Programme Grant

442 [The Integrative Cancer Epidemiology Programme, ICEP] (C18281/A19169). VT, KMB, CMP,

$443 \mathrm{JMPH}, \mathrm{NJT}$ are supported by ICEP (C18281/A19169). NJT is a Wellcome Trust Investigator

444 (202802/Z/16/Z) and works within the University of Bristol NIHR Biomedical Research Centre

445 (BRC). LJC is supported by NJT's Wellcome Trust Investigator grant (202802/Z/16/Z). NJT

446 and LJC work in the MRC IEU at the University of Bristol which is supported by the MRC 
447 (MC_UU_00011) and the University of Bristol. TD received support from Wellcome (grant ref 448 201268/Z/16/Z) and is now funded by the NIHR as an Academic Clinical Fellow. QQ is 449 supported by a Scientist Development Award (K01HL129892) from the NHLBI. JR is 450 supported in part by the National Center for Advancing Translational Sciences, CTSI grant 451 UL1TR001881, and the National Institute of Diabetes and Digestive and Kidney Disease 452 Diabetes Research Center (DRC) grant DK063491 to the Southern California Diabetes 453 Endocrinology Research Center. The views expressed are those of the authors and not 454 necessarily those of the NHS, the NIHR, or the Department of Health. This publication is the 455 work of the authors who will serve as guarantors for the contents of this paper.

\section{Acknowledgements}

457 Quality Control filtering of the UK Biobank data was conducted by R.Mitchell, G.Hemani, 458 T.Dudding, L.Paternoster as described in the published protocol 459 (doi:10.5523/bris.3074krb6t2frj29yh2b03x3wxj). SHIP is part of the Community Medicine 460 Research net of the University of Greifswald, Germany, which is funded by the Federal 461 Ministry of Education and Research (grants no. 01ZZ9603, 01ZZ0103, and 01ZZ0403), the 462 Ministry of Cultural Affairs as well as the Social Ministry of the Federal State of Mecklenburg463 West Pomerania, and the network 'Greifswald Approach to Individualized Medicine

464 (GANI_MED)' funded by the Federal Ministry of Education and Research (grant 03IS2061A). 465

\section{Tables and Figures}

467 Figure 1. Flow diagram of study design.

468 Figure 2. Estimates of the causal relationship between circulating lipid traits and overall breast 469 cancer in BCAC and UK Biobank.

470 Figure 3. Estimates of the causal relationship between circulating IGF traits and overall breast 471 cancer in BCAC and UK Biobank.

472 Table 1. Estimates of the causal relationship between lipids and breast cancer stratified by 473 ER status or menopausal status.

474 Table 2. Beta estimates of SD unit change in IGF-I and IGFBP-3 per SD unit increase in HDL475 C, LDL-C or TG based on observational analyses in SHIP.

476 Table 3. Beta estimates of SD unit change in IGF-I and IGFBP-3 per SD unit increase in HDL- 
medRxiv preprint doi: https://doi.org/10.1101/2020.06.04.20122630; this version posted June 7, 2020. The copyright holder for this preprint (which was not certified by peer review) is the author/funder, who has granted medRxiv a license to display the preprint in perpetuity.

All rights reserved. No reuse allowed without permission.

C, LDL-C or TG based on two-sample and multivariable Mendelian Randomisation analyses.

478 Table 4. Beta estimates of SD unit change in LDL-C, HDL-C and triglycerides per SD unit

479 increase in IGF-I or IGFBP-3 based on two-sample and multivariable Mendelian

480 randomization analyses.

481 Table 5. Estimates of the causal relationship between IGF-I or IGFBP-3 and breast cancer

482 risk stratified by ER or menopausal status.

483 Table 6. Multivariable MR analysis of the association of LDL-C and TG with breast cancer 484 conditioned on IGFs.

485

486

Table 7. Estimates of the causal relationship between LDL-C raising variants in HMGCR with breast cancer or IGF levels.

488 Supplementary Table 1. Genetic instruments used to construct genetic risk scores for lipid traits used in multivariable MR analyses

490 Supplementary Table 2. Genetic instruments used to construct genetic risk scores for IGF-I 491 and IGFBP-3

492 Supplementary Table 3. Study characteristics of the SHIP cohort

493 Supplementary Table 4. Association of IGF axis and lipids with potential confounders in the 494 SHIP study

\section{References}

4971 Torre, L. A. et al. Global cancer statistics, 2012. CA Cancer J Clin 65, 87$498 \quad$ 108, doi:10.3322/caac.21262 (2015).

4992 Siegel, R., Naishadham, D. \& Jemal, A. Cancer statistics, 2012. CA Cancer J

$500 \quad$ Clin 62, 10-29, doi:10.3322/caac.20138 (2012).

5013 Garcia-Estevez, L. \& Moreno-Bueno, G. Updating the role of obesity and cholesterol in breast cancer. Breast Cancer Res 21, 35, doi:10.1186/s13058-019-1124-1 (2019).

4 Blucher, C. \& Stadler, S. C. Obesity and Breast Cancer: Current Insights on the Role of Fatty Acids and Lipid Metabolism in Promoting Breast Cancer Growth and Progression. Front Endocrinol (Lausanne) 8, 293, doi:10.3389/fendo.2017.00293 (2017).

5 Touvier, M. et al. Cholesterol and breast cancer risk: a systematic review and meta-analysis of prospective studies. Br J Nutr 114, 347-357, doi:10.1017/S000711451500183X (2015).

6 Ni, H., Liu, H. \& Gao, R. Serum Lipids and Breast Cancer Risk: A MetaAnalysis of Prospective Cohort Studies. PloS one 10, e0142669, doi:10.1371/journal.pone.0142669 (2015).

$515 \quad$ Cancer Res 9, 10-19 (2003). 
medRxiv preprint doi: https://doi.org/10.1101/2020.06.04.20122630; this version posted June 7, 2020. The copyright holder for this preprint (which was not certified by peer review) is the author/funder, who has granted medRxiv a license to display the preprint in perpetuity.

All rights reserved. No reuse allowed without permission.

5168 Islam, M. M. et al. Exploring association between statin use and breast

$517 \quad$ cancer risk: an updated meta-analysis. Arch Gynecol Obstet 296, 1043-

$518 \quad$ 1053, doi:10.1007/s00404-017-4533-3 (2017).

5199 Suissa, S. Immortal time bias in observational studies of drug effects.

$520 \quad$ Pharmacoepidemiol Drug Saf 16, 241-249, doi:10.1002/pds.1357 (2007).

52110 Davey Smith, G. \& Hemani, G. Mendelian randomization: genetic anchors

522 for causal inference in epidemiological studies. Human molecular genetics

523

524

525

526

527

528

529

530

531 23, R89-98, doi:10.1093/hmg/ddu328 (2014).

11 Nowak, C. \& Arnlov, J. A Mendelian randomization study of the effects of blood lipids on breast cancer risk. Nature communications $\mathbf{9}, 3957$, doi:10.1038/s41467-018-06467-9 (2018).

12 Walker, V. M., Davey Smith, G., Davies, N. M. \& Martin, R. M. Mendelian randomization: a novel approach for the prediction of adverse drug events and drug repurposing opportunities. International journal of epidemiology 46, 2078-2089, doi:10.1093/ije/dyx207 (2017).

14 Orho-Melander, M. et al. Blood lipid genetic scores, the HMGCR gene and cancer risk: a Mendelian randomization study. International journal of epidemiology 47, 495-505, doi:10.1093/ije/dyx237 (2018). Bergen, K., Brismar, K. \& Tehrani, S. High-dose atorvastatin is associated with lower IGF-1 levels in patients with type 1 diabetes. Growth hormone \& IGF research : official journal of the Growth Hormone Research Society and the International IGF Research Society 29, 78-82, doi:10.1016/j.ghir.2016.06.001 (2016). dose-related changes in IGF bioavailability. European journal of endocrinology 168, 543-548, doi:10.1530/EJE-12-0844 (2013). reductase inhibitors on the concentration of insulin-like growth factor-1 (IGF-1) in hypercholesterolemic patients. Pharmacological reports : PR 61, 654-664 (2009).

18 Perks, C. M. \& Holly, J. M. IGF binding proteins (IGFBPs) and regulation of breast cancer biology. J Mammary Gland Biol Neoplasia 13, 455-469, doi:10.1007/s10911-008-9106-4 (2008).

19 Perks, C. M. \& Holly, J. M. Insulin-like growth factor binding proteins (IGFBPs) in breast cancer. J Mammary Gland Biol Neoplasia 5, 75-84 (2000).

20 Biernacka, K. M., Perks, C. M. \& Holly, J. M. Role of the IGF axis in prostate cancer. Minerva Endocrinol 37, 173-185 (2012).

559

21 Pollak, M. The insulin and insulin-like growth factor receptor family in neoplasia: an update. Nat Rev Cancer 12, 159-169, doi:10.1038/nrc3215 (2012).

22 Endogenous, H. et al. Insulin-like growth factor 1 (IGF1), IGF binding protein 3 (IGFBP3), and breast cancer risk: pooled individual data analysis of 17 prospective studies. Lancet Oncol 11, 530-542, doi:10.1016/S1470-2045(10)70095-4 (2010). 
medRxiv preprint doi: https://doi.org/10.1101/2020.06.04.20122630; this version posted June 7, 2020. The copyright holder for this preprint (which was not certified by peer review) is the author/funder, who has granted medRxiv a license to display the preprint in perpetuity.

All rights reserved. No reuse allowed without permission.

56523 Clemmons, D. R. Metabolic actions of insulin-like growth factor-I in

566

567

568

569

570

571

572

573

574

575

576

577

578

579

580

581

582

583

584

585

586

587

588

589

590

591

592

593

594

595

596

597

598

599

600

601

602

603

604

605

606

607

608

609

610

611

612 normal physiology and diabetes. Endocrinology and metabolism clinics of North America 41, 425-443, vii-viii, doi:10.1016/j.ecl.2012.04.017 (2012).

24 Kim, H. S. Role of insulin-like growth factor binding protein-3 in glucose and lipid metabolism. Ann Pediatr Endocrinol Metab 18, 9-12, doi:10.6065/apem.2013.18.1.9 (2013).

25 Russo, V. C., Azar, W. J., Yau, S. W., Sabin, M. A. \& Werther, G. A. IGFBP-2: The dark horse in metabolism and cancer. Cytokine Growth Factor Rev 26, 329-346, doi:10.1016/j.cytogfr.2014.12.001 (2015).

26 Mauras, N., Martinez, V., Rini, A. \& Guevara-Aguirre, J. Recombinant human insulin-like growth factor I has significant anabolic effects in adults with growth hormone receptor deficiency: studies on protein, glucose, and lipid metabolism. J Clin Endocrinol Metab 85, 3036-3042, doi:10.1210/jcem.85.9.6772 (2000).

27 Mauras, N. et al. Insulin-like growth factor I and growth hormone (GH) treatment in GH-deficient humans: differential effects on protein, glucose, lipid, and calcium metabolism. J Clin Endocrinol Metab 85, 1686-1694, doi:10.1210/jcem.85.4.6541 (2000).

28 Mauras, N. \& Haymond, M. W. Metabolic effects of recombinant human insulin-like growth factor-I in humans: comparison with recombinant human growth hormone. Pediatr Nephrol 10, 318-323 (1996).

29 Friedrich, N. et al. Cross-sectional and longitudinal associations between insulin-like growth factor I and metabolic syndrome: a general population study in German adults. Diabetes/metabolism research and reviews 29, 452-462, doi:10.1002/dmrr.2412 (2013).

30 Lam, C. S. et al. Circulating insulin-like growth factor-1 and its binding protein-3: metabolic and genetic correlates in the community. Arteriosclerosis, thrombosis, and vascular biology 30, 1479-1484, doi:10.1161/ATVBAHA.110.203943 (2010).

31 Eggert, M. L. et al. Cross-sectional and longitudinal relation of IGF1 and IGF-binding protein 3 with lipid metabolism. European journal of endocrinology 171, 9-19, doi:10.1530/EJE-13-1017 (2014).

32 Melvin, J. C., Holmberg, L., Rohrmann, S., Loda, M. \& Van Hemelrijck, M. Serum lipid profiles and cancer risk in the context of obesity: four metaanalyses. J Cancer Epidemiol 2013, 823849, doi:10.1155/2013/823849 (2013).

33 Chandler, P. D. et al. Lipid biomarkers and long-term risk of cancer in the Women's Health Study. Am J Clin Nutr 103, 1397-1407, doi:10.3945/ajen.115.124321 (2016).

34 Pollak, M. Insulin and insulin-like growth factor signalling in neoplasia. Nat Rev Cancer 8, 915-928, doi:10.1038/nrc2536 (2008).

35 Relton, C. L. \& Davey Smith, G. Two-step epigenetic Mendelian randomization: a strategy for establishing the causal role of epigenetic processes in pathways to disease. International journal of epidemiology 41, 161-176, doi:10.1093/ije/dyr233 (2012).

36 Global Lipids Genetics, C. et al. Discovery and refinement of loci associated with lipid levels. Nature genetics 45, 1274-1283, doi:10.1038/ng.2797 (2013). 
61337 Michailidou, K. et al. Association analysis identifies 65 new breast cancer

614

615

616

617

618

619

620

621

622

623

624

625

626

627

628

629

630

631

632

633

634

635

636

637

638

639

640

641

642

643

644

645

646

647

648

649

650

651

652

653

654

655

656

657

658

659

660

risk loci. Nature 551, 92-94, doi:10.1038/nature24284 (2017).

38 Teumer, A. et al. Genomewide meta-analysis identifies loci associated with IGF-I and IGFBP-3 levels with impact on age-related traits. Aging cell 15, 811-824, doi:10.1111/acel.12490 (2016).

39 Yarmolinsky, J. et al. Association Between Genetically Proxied Inhibition of HMG-CoA Reductase and Epithelial Ovarian Cancer. JAMA 323, 646655, doi:10.1001/jama.2020.0150 (2020).

40 Burgess, S., Dudbridge, F. \& Thompson, S. G. Re: "Multivariable Mendelian randomization: the use of pleiotropic genetic variants to estimate causal effects". American journal of epidemiology 181, 290-291, doi:10.1093/aje/kwv017 (2015).

41 Burgess, S. \& Thompson, S. G. Multivariable Mendelian randomization: the use of pleiotropic genetic variants to estimate causal effects. American journal of epidemiology 181, 251-260, doi:10.1093/aje/kwu283 (2015).

42 Lawlor, D. A. Commentary: Two-sample Mendelian randomization: opportunities and challenges. International journal of epidemiology 45, 908-915, doi:10.1093/ije/dyw127 (2016).

43 Burgess, S., Butterworth, A. \& Thompson, S. G. Mendelian randomization analysis with multiple genetic variants using summarized data. Genetic epidemiology 37, 658-665, doi:10.1002/gepi.21758 (2013).

44 Bowden, J., Davey Smith, G. \& Burgess, S. Mendelian randomization with invalid instruments: effect estimation and bias detection through Egger regression. International journal of epidemiology 44, 512-525, doi:10.1093/ije/dyv080 (2015).

45 Bowden, J., Davey Smith, G., Haycock, P. C. \& Burgess, S. Consistent Estimation in Mendelian Randomization with Some Invalid Instruments Using a Weighted Median Estimator. Genetic epidemiology 40, 304-314, doi:10.1002/gepi.21965 (2016).

46 Burgess, S. et al. Using published data in Mendelian randomization: a blueprint for efficient identification of causal risk factors. Eur J Epidemiol 30, 543-552, doi:10.1007/s10654-015-0011-z (2015).

47 Sanderson, E., Davey Smith, G., Windmeijer, F. \& Bowden, J. An examination of multivariable Mendelian randomization in the singlesample and two-sample summary data settings. International journal of epidemiology 48, 713-727, doi:10.1093/ije/dyy262 (2019).

48 Sanderson, E., Spiller, W., Bowden, J. . Testing and Correcting for Weak and Pleiotropic Instruments in Two-Sample Multivariable Mendelian Randomisation. bioRxiv, doi:https://doi.org/10.1101/2020.04.02.021980 (2020).

49 Yavorska, 0. 0. \& Burgess, S. MendelianRandomization: an R package for performing Mendelian randomization analyses using summarized data. International journal of epidemiology 46, 1734-1739, doi:10.1093/ije/dyx034 (2017).

50 Burgess, S., Dudbridge, F. \& Thompson, S. G. Combining information on multiple instrumental variables in Mendelian randomization: comparison of allele score and summarized data methods. Stat Med 35, 1880-1906, doi:10.1002/sim.6835 (2016). 
medRxiv preprint doi: https://doi.org/10.1101/2020.06.04.20122630; this version posted June 7, 2020. The copyright holder for this preprint (which was not certified by peer review) is the author/funder, who has granted medRxiv a license to display the preprint in perpetuity.

All rights reserved. No reuse allowed without permission.

$66151 \quad$ Hemani, G. et al. The MR-Base platform supports systematic causal

662 inference across the human phenome. Elife 7, doi:10.7554/eLife.34408

663 (2018).

66452 Holmes, M. V., Ala-Korpela, M. \& Smith, G. D. Mendelian randomization in

665

666

667 cardiometabolic disease: challenges in evaluating causality. Nat Rev Cardiol 14, 577-590, doi:10.1038/nrcardio.2017.78 (2017).

668

669

670

671

672

673

674

675

53

Bonilla, C. et al. Assessing the role of insulin-like growth factors and binding proteins in prostate cancer using Mendelian randomization: Genetic variants as instruments for circulating levels. International journal of cancer 139, 1520-1533, doi:10.1002/ijc.30206 (2016).

54 Kaaks, R. et al. Insulin-like growth factor I and risk of breast cancer by age and hormone receptor status-A prospective study within the EPIC cohort. International journal of cancer 134, 2683-2690, doi:10.1002/ijc.28589 (2014).

55 Surmacz, E. \& Bartucci, M. Role of estrogen receptor alpha in modulating IGF-I receptor signaling and function in breast cancer. J Exp Clin Cancer Res 23, 385-394 (2004).

679

680

56 Auro, K. et al. A metabolic view on menopause and ageing. Nature communications 5, 4708, doi:10.1038/ncomms5708 (2014).

681

682

683 Agnoli, C. et al. Metabolic syndrome and postmenopausal breast cancer in the ORDET cohort: a nested case-control study. Nutr Metab Cardiovasc Dis 20, 41-48, doi:10.1016/j.numecd.2009.02.006 (2010).

687 high-density lipoprotein cholesterol, metabolic profile, and breast cancer risk. J Natl Cancer Inst 96, 1152-1160, doi:10.1093/jnci/djh216 (2004).

60 Moorman, P. G. et al. Association between high-density lipoprotein cholesterol and breast cancer varies by menopausal status. Cancer epidemiology, biomarkers \& prevention : a publication of the American Association for Cancer Research, cosponsored by the American Society of Preventive Oncology 7, 483-488 (1998).

695

61 Swerdlow, D. I. et al. Selecting instruments for Mendelian randomization in the wake of genome-wide association studies. International journal of 
(i) Two sample Mendelian Randomization (MR) analyses to estimate the causal relationships between lipids and $\mathrm{BCa}$ risk

Lipid GWAS (GLGC consortium) identified 185 SNPs associated with LDL-C, HDL-C and TG $(n=188,577)$

\section{$\downarrow$}

SNPs associated with lipids were extracted from the BCa GWAS conducted in: BCAC consortium ( $n=122,977$ cases and 105,974 controls) and UK Biobank ( $n=15,349$ cases and 215,605 controls)

\section{$\downarrow$}

Multivariable MR analyses were conducted to estimate the causal relationship between lipids with overall BCa risk ( $n=228,951$ for BCAC and $n=230,954$ for UKBB). Analyses were also conducted stratified by ER status ( $n=69,501$ for

ER positive and $n=21,468$ for ER negative) and menopausal status.

( $n=59,124$ for premenopausal BCa and $n=112,245$ for postmenopausal BCa)

(ii) Observational analyses to investigate the relationship between lipid traits and IGFs

Circulating lipid (LDL-C, HDL-C and TG) and IGF (IGF-I and IGFBP-3) traits were measured in blood samples collected from 3812 individuals from the Study of Health in Pomerania (SHIP) study

inear regression analyses were carried out to assess the association between circulating lipids and IGFs.

(iii) Two sample bidirectional MR analyses to investigate the causal relationship between lipids with IGF-I and IGFBP-3

Lipid GWAS (GLGC consortium) identified 185 SNPs associated with LDL-C, HDL-C and TG $(n=188,577)$

\section{1}

SNPs associated with lipids were extracted from the IGF GWAS GWAS conducted by IGF working group of the CHARGE consortium

(IGF-I n=30,884 and IGFBP-3 n=18,995)

Two sample MR analyses were conducted to estimate the causal relationship between lipids with IGF-I and IGFBP-3
IGF GWAS (IGF working group of the CHARGE consortium) identified 7 and 4 SNPs associated with IGF-I $(n=30,884)$ and IGFBP-3 $(n=18,995)$ respectively

\section{$\downarrow$}

SNPs associated with IGF-I and IGFBP-3 were extracted from the lipids GWAS conducted by GLGC $(n=188,577)$

Two sample MR analyses were conducted to estimate the causal relationship between IGF-I and IGFBP-3 with lipids

(iv) Two sample Mendelian Randomization (MR) analyses to estimate the causal relationships between IGFs and BCa risk

IGF GWAS (IGF working group of the CHARGE consortium) identified 7 and 4 SNPs associated with IGF-I $(n=30,884)$ and IGFBP-3 $(n=18,995)$

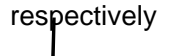

SNPs associated with IGF-I and IGFBP-3 were extracted from the BCa GWAS conducted in the BCAC consortium ( $n=122,977$ cases and 105,974 controls) and in UK Biobank ( $n=15,349$ cases and 215,605 controls)

Two sample MR analyses were conducted to estimate the causal relationship between IGF-I or IGFBP-3 and overall BCa risk ( $n=228,951$ for BCAC and $n=230,954$
for UKBB). Analyses were also conducted stratified by ER status $(n=69,501$ for ER

positive and $n=21,468$ for ER negative) and menopausal status. ( $n=59,124$ for premenopausal $\mathrm{BCa}$ and $\mathrm{n}=112,245$ for postmenopausal $\mathrm{BCa}$ )

(v) Two sample Mendelian Randomization (MR) analyses to estimate the causal relationship between statin use and $\mathrm{BC}$ a risk

We constructed a genetic instrument to proxy statin treatment by selecting 5 weakly correlated SNPs within 100kb of HMGCR that was robustly associated with LDL-C levels in the lipid GWAS (GLGC consortium) $(n=188,577)$

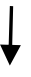

5 SNPs in HMGCR were extracted from the BCa GWAS conducted in: cases and 105,974 controls) and

\section{$\downarrow$}

MR analyses were conducted to reassess the causal relationship between statin use and $\mathrm{BCa}$ risk
5 SNPs in HMGCR were extracted from the IGF GWAS conducted by IGF working group of the CHARGE consortium

(IGF-I n=30,884 and IGFBP-3 n=18,995)

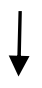

MR analyses were conducted to estimate the causal relationship between statin use with IGF-I and IGFBP-3

Figure 1. Flow diagram of study design. 


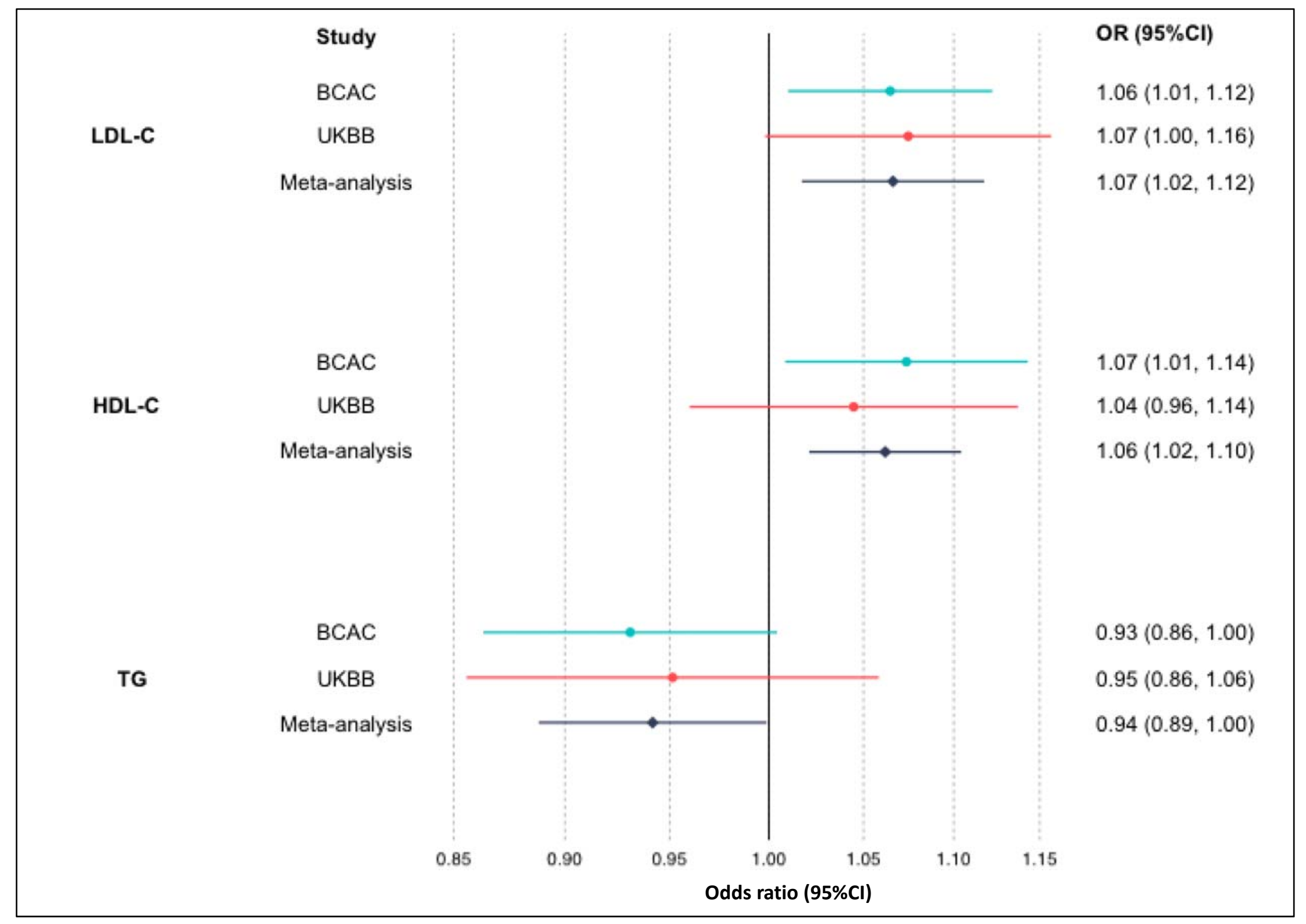

Figure 2. Estimates of the causal relationship between circulating lipid traits and breast cancer risk in BCAC and UK Biobank.

The forest plot shows the estimate of the causal effect of LDL-C, HDL-C and TG on overall breast cancer risk using summary data from the breast cancer association consortium (BCAC) ( $n=122,977$ cases and 105,974 controls) and UK Biobank (UKBB) ( $n=15,349$ cases and 215,605 controls). Squares represent point estimates from individual analyses. Horizontal lines represent the $95 \%$ confidence intervals. Pooled estimates (represented by diamonds) were obtained using random-effects meta-analysis. 


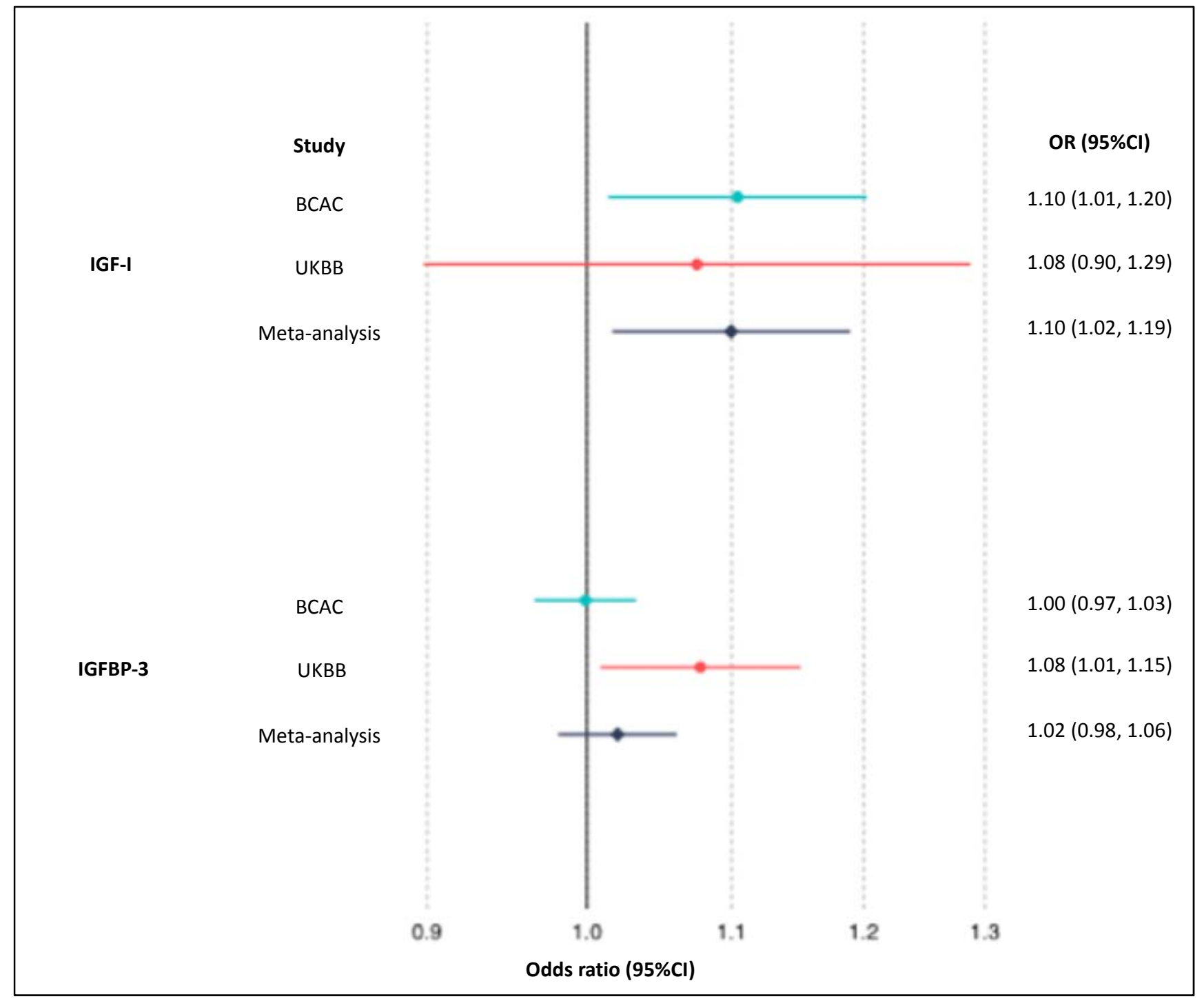

Figure 3. Estimates of the causal relationship between circulating IGF traits and breast cancer risk in BCAC and UK Biobank.

The forest plot shows the estimate of the causal effect of IGF-I and IGFBP-3 on breast cancer risk using summary data from the breast cancer association consortium (BCAC) ( $n=122,977$ cases and 105,974 controls) and UK Biobank (UKBB) ( $n=15,349$ cases and 215,605 controls). Squares represent point estimates from individual analyses. Horizontal lines represent the $95 \%$ confidence intervals. Pooled estimates (represented by diamonds) were obtained using random effects meta-analysis. 
medRxiv preprint doi: https://doi.org/10.1101/2020.06.04.20122630; this version posted June 7, 2020. The copyright holder for this preprint (which was not certified by peer review) is the author/funder, who has granted medRxiv a license to display the preprint in perpetuity.

All rights reserved. No reuse allowed without permission.

Table 1. Estimates of the causal relationship between lipids and breast cancer stratified by ER status or menopausal status.

\begin{tabular}{|c|c|c|c|c|c|}
\hline Exp & Consortium & Outcome & $\mathbf{N}$ & $\begin{array}{c}\mathrm{OR}^{\mathrm{a}} \\
(95 \% \mathrm{Cl})\end{array}$ & $p$ \\
\hline \multirow[t]{2}{*}{ LDL-C } & BCAC & ER positive $\mathrm{BCa}$ & 69,501 & $\begin{array}{c}1.06 \\
(0.99,1.12)\end{array}$ & 0.07 \\
\hline & BCAC & ER negative $\mathrm{BCa}$ & 21,468 & $\begin{array}{c}1.05 \\
(0.98,1.13)\end{array}$ & 0.16 \\
\hline \multirow[t]{2}{*}{ HDL-C } & BCAC & ER positive $\mathrm{BCa}$ & 69,501 & $\begin{array}{c}1.08 \\
(1.01,1.15)\end{array}$ & 0.04 \\
\hline & BCAC & ER negative $\mathrm{BCa}$ & 21,468 & $\begin{array}{c}1.08 \\
(0.99,1.18)\end{array}$ & 0.09 \\
\hline \multirow[t]{2}{*}{ TG } & BCAC & ER positive $\mathrm{BCa}$ & 69,501 & $\begin{array}{c}0.93 \\
(0.86,1.02)\end{array}$ & 0.11 \\
\hline & BCAC & ER negative $\mathrm{BCa}$ & 21,468 & $\begin{array}{c}0.92 \\
(0.83,1.02) \\
\end{array}$ & 0.11 \\
\hline \multirow[t]{2}{*}{ LDL-C } & UKBB & Premenopause $\mathrm{BCa}$ & 59,124 & $\begin{array}{c}1.07 \\
(0.91,1.26)\end{array}$ & 0.42 \\
\hline & UKBB & Postmenopause $\mathrm{BCa}$ & 112,245 & $\begin{array}{c}1.14 \\
(1.04,1.25)\end{array}$ & 0.004 \\
\hline \multirow[t]{2}{*}{ HDL-C } & UKBB & Premenopause $\mathrm{BCa}$ & 59,124 & $\begin{array}{c}1.07 \\
(0.89,1.30)\end{array}$ & 0.46 \\
\hline & UKBB & Postmenopause $\mathrm{BCa}$ & 112,245 & $\begin{array}{c}1.02 \\
(0.93,1.13)\end{array}$ & 0.64 \\
\hline \multirow[t]{2}{*}{ TG } & UKBB & Premenopause $\mathrm{BCa}$ & 59,124 & $\begin{array}{c}1.02 \\
(0.81,1.30)\end{array}$ & 0.84 \\
\hline & UKBB & Postmenopause $\mathrm{BCa}$ & 112,245 & $\begin{array}{c}0.91 \\
(0.80,1.03) \\
\end{array}$ & 0.14 \\
\hline
\end{tabular}

OR, odds ratio; 95\% $\mathrm{Cl}, 95 \%$ confidence interval; $p$, p-value; HDL-C, high density lipoprotein cholesterol; LDL-C, low density lipoprotein cholesterol; TG, triglycerides; MR, Mendelian randomization; $\mathrm{BCa}$, Breast cancer; BCAC, breast cancer association consortium; UKBB, UK Biobank; ER, estrogen receptor.

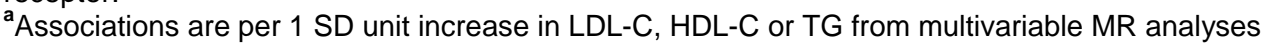


medRxiv preprint doi: https://doi.org/10.1101/2020.06.04.20122630; this version posted June 7, 2020. The copyright holder for this preprint (which was not certified by peer review) is the author/funder, who has granted medRxiv a license to display the preprint in perpetuity.

All rights reserved. No reuse allowed without permission.

Table 2. Beta estimates of SD unit change in IGF-I and IGFBP-3 per SD unit increase in HDL-C, LDL-C or TG based on observational analyses in SHIP.

\begin{tabular}{|c|c|c|c|c|c|c|}
\hline \multirow[b]{2}{*}{ Exposure } & \multirow[b]{2}{*}{ Outcome } & \multirow[b]{2}{*}{$\mathbf{N}$} & \multicolumn{2}{|c|}{ Unadjusted } & \multicolumn{2}{|c|}{ Adjusted $^{\mathrm{a}}$} \\
\hline & & & $\begin{array}{l}\text { Beta }^{\mathrm{b}} \\
(95 \% \mathrm{Cl})\end{array}$ & $p$ & $\begin{array}{l}\text { Beta }^{b} \\
(95 \% \mathrm{Cl})\end{array}$ & $p$ \\
\hline LDL-C & IGF-I & 3812 & $\begin{array}{c}-0.11 \\
(-0.14,-0.08)\end{array}$ & $2 \times 10^{-12}$ & $\begin{array}{c}0.03 \\
(0.004,0.06)\end{array}$ & 0.03 \\
\hline HDL-C & IGF-I & 3812 & $\begin{array}{c}0.02 \\
(-0.01,0.05)\end{array}$ & 0.29 & $\begin{array}{c}-0.05 \\
(-0.08,-0.02)\end{array}$ & 0.001 \\
\hline TG & IGF-I & 3812 & $\begin{array}{c}-0.16 \\
(-0.19,-0.13)\end{array}$ & $2 \times 10^{-22}$ & $\begin{array}{c}-0.06 \\
(-0.09,-0.04)\end{array}$ & $1.5 \times 10^{-5}$ \\
\hline LDL-C & IGFBP-3 & 3812 & $\begin{array}{c}-0.01 \\
(-0.04,0.02)\end{array}$ & 0.47 & $\begin{array}{c}0.08 \\
(0.05,0.11)\end{array}$ & $1.12 \times 10^{-7}$ \\
\hline HDL-C & IGFBP-3 & 3812 & $\begin{array}{c}0.06 \\
(0.03,0.10)\end{array}$ & $7.01 \times 10^{-5}$ & $\begin{array}{c}-0.02 \\
(-0.05,0.02)\end{array}$ & 0.30 \\
\hline TG & IGFBP-3 & 3812 & $\begin{array}{c}0.03 \\
(-0.003,0.06)\end{array}$ & 0.08 & $\begin{array}{c}0.13 \\
(0.10,0.16)\end{array}$ & $2.69 \times 10^{-15}$ \\
\hline
\end{tabular}

$\mathrm{N}$, sample size; Beta, regression coefficient; $95 \% \mathrm{Cl}$, 95\% confidence interval; $p$, p-value; HDL-C, high density lipoprotein cholesterol; LDL-C, low density lipoprotein cholesterol; TG, triglycerides; IGF-I, insulin-like growth factor 1; IGFBP-3, insulin-like growth factor binding protein 3

${ }^{a}$ Analyses were adjusted for age, gender, smoking status, body mass index and diabetes status ${ }^{\mathbf{b}}$ Beta refers to the $\mathrm{s} . \mathrm{d}$ unit change in IGF-I or IGFBP-3 levels per $1 \mathrm{~s} . \mathrm{d}$ unit decrease in HDL-C, LDL-C or TG. 
medRxiv preprint doi: https://doi.org/10.1101/2020.06.04.20122630; this version posted June 7, 2020. The copyright holder for this preprint (which was not certified by peer review) is the author/funder, who has granted medRxiv a license to display the preprint in perpetuity.

All rights reserved. No reuse allowed without permission.

Table 3. Beta estimates of SD unit change in IGF-I and IGFBP-3 per SD unit increase in HDL-C, LDL-C or TG based on two-sample and multivariable Mendelian randomization analyses.

\begin{tabular}{|c|c|c|c|c|c|c|c|c|c|}
\hline \multirow[b]{2}{*}{ Exposure } & \multirow[b]{2}{*}{ Outcome } & \multicolumn{2}{|c|}{ Main analysis } & \multicolumn{6}{|c|}{ Sensitivity analyses } \\
\hline & & $\begin{array}{c}\text { IVW } \\
\text { Beta }^{a} \\
(95 \% \mathrm{Cl})\end{array}$ & $p$ & $\begin{array}{l}\text { Weighted } \\
\text { Median } \\
\text { Beta }^{\mathrm{a}} \\
(95 \% \mathrm{Cl})\end{array}$ & $p$ & $\begin{array}{l}\text { MR Egger } \\
\text { regression } \\
\text { Beta }^{a} \\
(95 \% \mathrm{Cl})\end{array}$ & $p$ & $\begin{array}{c}\text { Multivariable } \\
\text { MR } \\
\text { Beta }^{a} \\
(95 \% \mathrm{Cl})\end{array}$ & $p$ \\
\hline LDL-C & IGF-I & $\begin{array}{c}0.01 \\
(-0.04,0.07)\end{array}$ & 0.64 & $\begin{array}{c}0.02 \\
(-0.05,0.09)\end{array}$ & 0.64 & $\begin{array}{c}0.001 \\
(-0.09,0.10)\end{array}$ & 0.99 & $\begin{array}{c}0.04 \\
(-0.02,0.10)\end{array}$ & 0.21 \\
\hline HDL-C & IGF-I & $\begin{array}{c}0.01 \\
(-0.05,0.07)\end{array}$ & 0.80 & $\begin{array}{c}-0.01 \\
(-0.08,0.07)\end{array}$ & 0.87 & $\begin{array}{c}0.03 \\
(-0.08,0.13)\end{array}$ & 0.62 & $\begin{array}{c}-0.02 \\
(-0.08,0.04)\end{array}$ & 0.56 \\
\hline TG & IGF-I & $\begin{array}{c}-0.13 \\
(-0.22,-0.03)\end{array}$ & 0.01 & $\begin{array}{c}-0.04 \\
(-0.13,0.06)\end{array}$ & 0.46 & $\begin{array}{c}-0.23 \\
(-0.39,-0.07)\end{array}$ & 0.01 & $\begin{array}{c}-0.12 \\
(-0.18,-0.06)\end{array}$ & $<0.001$ \\
\hline LDL-C & IGFBP-3 & $\begin{array}{c}0.08 \\
(0.02,0.15)\end{array}$ & 0.01 & $\begin{array}{c}0.05 \\
(-0.03,0.12)\end{array}$ & 0.26 & $\begin{array}{c}0.09 \\
(-0.02,0.20)\end{array}$ & 0.10 & $\begin{array}{c}0.08 \\
(0.02,0.14)\end{array}$ & 0.01 \\
\hline HDL-C & IGFBP-3 & $\begin{array}{c}-0.06 \\
(-0.13,0.01)\end{array}$ & 0.08 & $\begin{array}{c}-0.05 \\
(-0.17,0.06)\end{array}$ & 0.36 & $\begin{array}{c}-0.05 \\
(-0.17,0.06)\end{array}$ & 0.36 & $\begin{array}{c}-0.02 \\
(-0.08,0.04)\end{array}$ & 0.61 \\
\hline TG & IGFBP-3 & $\begin{array}{c}0.10 \\
(0.01,0.19)\end{array}$ & 0.03 & $\begin{array}{c}0.08 \\
(-0.03,0.19)\end{array}$ & 0.14 & $\begin{array}{c}0.13 \\
(-0.02,0.27)\end{array}$ & 0.10 & $\begin{array}{c}0.06 \\
(0.001,0.12)\end{array}$ & 0.04 \\
\hline
\end{tabular}

$\mathrm{N}$, sample size; Beta, regression coefficient; IVW, inverse variance weighted; $95 \% \mathrm{Cl}, 95 \%$ confidence interval; $p$, $p$-value; MR, mendelian randomization; HDL-C, high density lipoprotein cholesterol; LDL-C, low density lipoprotein cholesterol; TG, triglycerides

${ }^{\mathrm{a}}$ Beta refers to the s.d unit change in IGF-I or IGFBP-3 levels per 1 s.d unit increase in HDL-C, LDL-C or TG. 
Table 4. Beta estimates of SD unit change in LDL-C, HDL-C and triglycerides per SD unit increase in IGF-I or IGFBP-3 based on two-sample and multivariable Mendelian randomization analyses.

\begin{tabular}{|c|c|c|c|c|c|}
\hline \multirow[b]{2}{*}{ Exposure } & \multirow[b]{2}{*}{ Outcome } & \multicolumn{2}{|c|}{ Main analysis } & \multicolumn{2}{|c|}{ Sensitivity analysis } \\
\hline & & $\begin{array}{c}\text { IVW } \\
\text { Beta }^{a} \\
(95 \% \mathrm{Cl})\end{array}$ & $p$ & $\begin{array}{c}\text { Multivariable MR } \\
\text { Beta }^{\mathrm{a}} \\
(95 \% \mathrm{Cl})\end{array}$ & $p$ \\
\hline IGF-I & LDL-C & $\begin{array}{c}-0.07 \\
(-0.21,0.08)\end{array}$ & 0.37 & $\begin{array}{c}-0.04 \\
(-0.18,0.10)\end{array}$ & 0.55 \\
\hline IGF-I & HDL-C & $\begin{array}{c}-0.02 \\
(-0.13,0.08)\end{array}$ & 0.65 & $\begin{array}{c}-0.01 \\
(-0.11,0.09)\end{array}$ & 0.77 \\
\hline IGF-I & TG & $\begin{array}{c}-0.39 \\
(-1.00,0.22)\end{array}$ & 0.21 & $\begin{array}{c}-0.35 \\
(-0.90,0.20)\end{array}$ & 0.20 \\
\hline IGFBP-3 & LDL-C & $\begin{array}{c}-0.01 \\
(-0.04,0.02)\end{array}$ & 0.60 & $\begin{array}{c}-0.01 \\
(-0.07,0.05)\end{array}$ & 0.81 \\
\hline IGFBP-3 & HDL-C & $\begin{array}{c}-0.002 \\
(-0.02,0.02)\end{array}$ & 0.87 & $\begin{array}{c}-0.01 \\
(-0.05,0.03)\end{array}$ & 0.69 \\
\hline IGFBP-3 & TG & $\begin{array}{c}-0.02 \\
(-0.05,0.02)\end{array}$ & 0.33 & $\begin{array}{c}0.02 \\
(-0.22,0.26)\end{array}$ & 0.90 \\
\hline
\end{tabular}

$\mathrm{N}$, sample size; Beta, regression coefficient; IVW, inverse variance weighted; $95 \% \mathrm{Cl}$, $95 \%$ confidence interval; $p$, $p$-value; HDL-C, high density lipoprotein cholesterol; LDL-C, low density lipoprotein cholesterol; TG, triglycerides

${ }^{\mathrm{a}}$ Beta refers to the s.d unit change in HDL-C, LDL-C, TG or TC per SD unit change in IGF-I and IGFBP3 levels. 
medRxiv preprint doi: https://doi.org/10.1101/2020.06.04.20122630; this version posted June 7, 2020. The copyright holder for this preprint (which was not certified by peer review) is the author/funder, who has granted medRxiv a license to display the preprint in perpetuity.

All rights reserved. No reuse allowed without permission.

Table 5. Estimates of the causal relationship between IGF-I or IGFBP-3 and breast cancer stratified by ER or menopausal status.

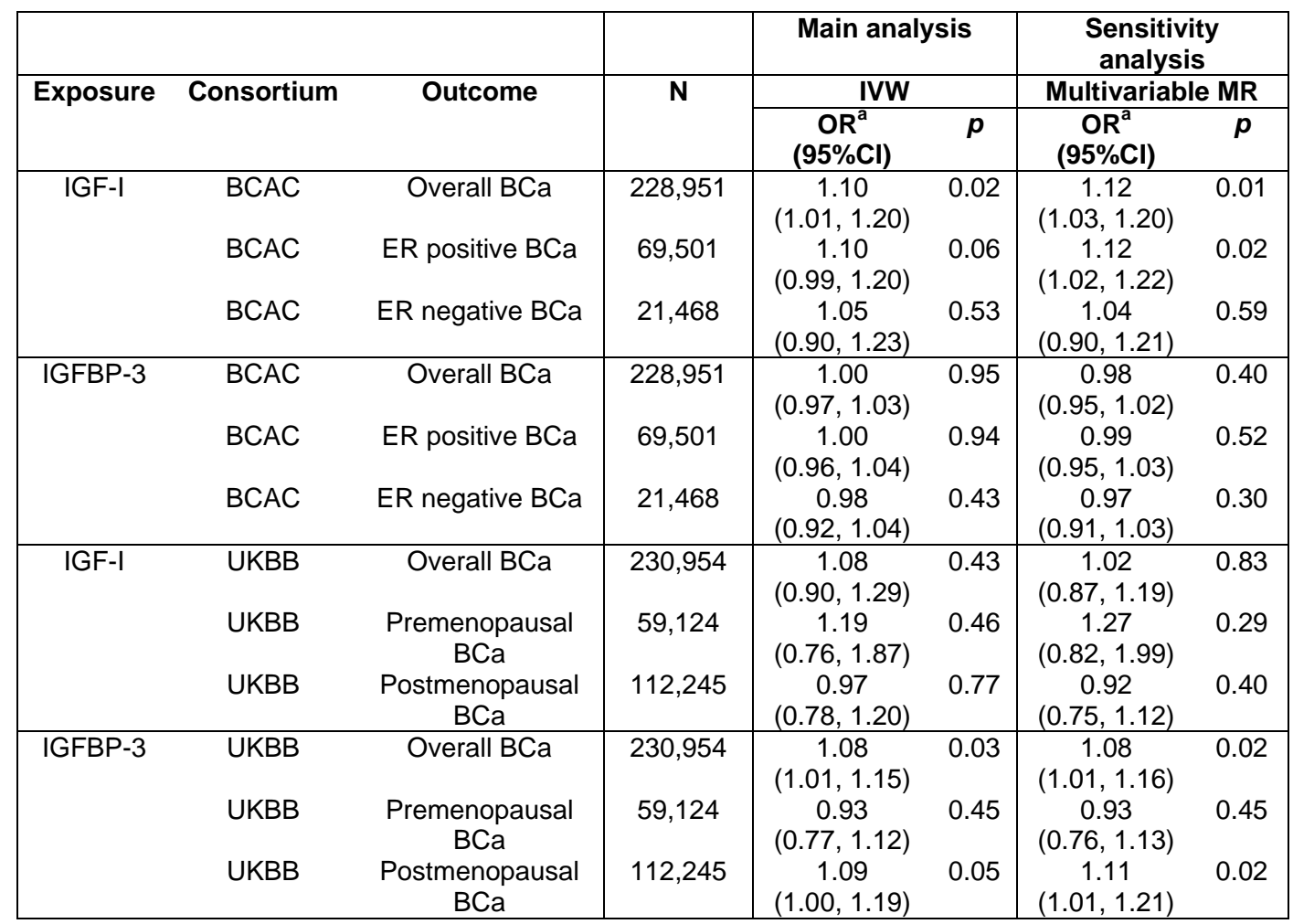

IVW, inverse variance weighted; OR, odds ratio; $95 \% \mathrm{Cl}, 95 \%$ confidence interval; $p$, $\mathrm{p}$-value; se, standard error; MR, Mendelian randomization; UKBB, UK Biobank; IGF-I, insulin-like growth factor I; IGFBP-3, insulin-like growth factor binding protein 3.

${ }^{a}$ Associations are per 1 SD unit increase in IGF-I or IGFBP-3. 
medRxiv preprint doi: https://doi.org/10.1101/2020.06.04.20122630; this version posted June 7, 2020. The copyright holder for this preprint (which was not certified by peer review) is the author/funder, who has granted medRxiv a license to display the preprint in perpetuity.

All rights reserved. No reuse allowed without permission.

Table 6. Multivariable MR analysis of the association of LDL-C and TG with breast cancer conditioned on IGFs.

\begin{tabular}{|c|c|c|c|c|c|c|}
\hline Exposure & Consortium & Outcome & $\begin{array}{c}\text { MVMR } \\
\text { Beta } \\
(95 \% \mathrm{Cl})\end{array}$ & $p$ & $\begin{array}{c}F \\
\text { statistic } \\
\text { for } \\
\text { MVMR }\end{array}$ & $\begin{array}{l}\text { Q statistic for } \\
\text { heterogeneity }\end{array}$ \\
\hline $\begin{array}{l}T^{a} \\
\text { IGF-I }\end{array}$ & BCAC & Overall $\mathrm{BCa}$ & $\begin{array}{c}0.92 \\
(0.86,1.10)\end{array}$ & 0.03 & $\begin{array}{l}17.80 \\
2.38\end{array}$ & $\begin{array}{c}Q=579.42 ; \\
p=4.1 \times 10^{-46}\end{array}$ \\
\hline $\begin{array}{c}T^{a} \\
p\end{array}$ & UKBB & Overall BCa & $\begin{array}{c}0.95 \\
(0.86,1.05)\end{array}$ & 0.25 & $\begin{array}{l}31.22 \\
2.42\end{array}$ & $\begin{array}{l}\mathrm{Q}=327.29 \\
p=1.74 \times 10^{-9}\end{array}$ \\
\hline $\begin{array}{c}T^{a} \\
\text { IGF-I }\end{array}$ & Meta-analysis & Overall BCa & $\begin{array}{c}0.93 \\
(0.88,0.99)\end{array}$ & 0.03 & & \\
\hline $\begin{array}{l}\text { LDL-C }^{b} \\
\text { IGFBP-3 }\end{array}$ & & $\begin{array}{c}\text { Postmenopausal } \\
\text { BCa }\end{array}$ & $\begin{array}{c}1.11 \\
(1.02,1.20)\end{array}$ & 0.02 & $\begin{array}{l}46.74 \\
5.34\end{array}$ & $\begin{array}{c}\mathrm{Q}=274.59 \\
p=4.71 \times 10^{-5}\end{array}$ \\
\hline
\end{tabular}

OR, odds ratio; 95\% $\mathrm{Cl}$, 95\% confidence interval; $p$, $\mathrm{p}$-value; LDL-C, low density lipoprotein cholesterol; MVMR, Multivariable Mendelian randomization; BCa, Breast cancer; IGFBP-3, insulin-like growth factor 3.

${ }^{\mathrm{a} A s s o c i a t i o n s}$ are per 1 SD unit increase in TG when conditioned on IGF-I.

${ }^{\mathbf{b}}$ Associations are per 1 SD unit increase in LDL-C when conditioned on IGFBP-3. 
medRxiv preprint doi: https://doi.org/10.1101/2020.06.04.20122630; this version posted June 7, 2020. The copyright holder for this preprint (which was not certified by peer review) is the author/funder, who has granted medRxiv a license to display the preprint in perpetuity.

All rights reserved. No reuse allowed without permission.

Table 7. Estimates of the causal relationship between LDL-C raising variants in HMGCR with breast cancer or IGF levels.

\begin{tabular}{|c|c|c|c|c|c|}
\hline Exposure & Consortium & Outcome & $\mathbf{N}$ & $\begin{array}{c}\text { OR }^{a} \\
(95 \% \mathrm{Cl})\end{array}$ & $p$ \\
\hline \multirow{9}{*}{$\begin{array}{l}L D L-C \\
\text { raising } \\
\text { genetic } \\
\text { variants in } \\
\text { HMGCR }\end{array}$} & BCAC & Overall BCa & 228,951 & $\begin{array}{c}1.20 \\
(1.02,1.40)\end{array}$ & 0.03 \\
\hline & UKBB & Overall $\mathrm{BCa}$ & 230,954 & $\begin{array}{c}1.34 \\
(0.90,2.02)\end{array}$ & 0.15 \\
\hline & Meta-analysis & Overall BCa & 459,905 & $\begin{array}{c}1.22 \\
(1.04,1.43)\end{array}$ & 0.01 \\
\hline & BCAC & ER positive $\mathrm{BCa}$ & 69,501 & $\begin{array}{c}1.21 \\
(1.00,1.47)\end{array}$ & 0.05 \\
\hline & BCAC & ER negative $\mathrm{BCa}$ & 21,468 & $\begin{array}{c}1.20 \\
(0.90,1.60)\end{array}$ & 0.23 \\
\hline & UKBB & Premenopausal BCa & 59,124 & $\begin{array}{c}1.47 \\
(0.57,3.75)\end{array}$ & 0.42 \\
\hline & UKBB & Postmenopausal BCa & 112,245 & $\begin{array}{c}1.63 \\
(1.06,2.49)\end{array}$ & 0.03 \\
\hline & IGF working group of & & 30,884 & $\begin{array}{c}0.20 \\
(-0.02,0.43)\end{array}$ & 0.07 \\
\hline & CHARGE consortium & IGFBP-3 levels & 18,995 & $\begin{array}{c}0.03 \\
(-0.24,0.30)\end{array}$ & 0.82 \\
\hline
\end{tabular}

OR, odds ratio; 95\% Cl, 95\% confidence interval; $p$, p-value; LDL-C, low density lipoprotein cholesterol; HMGCR, HMG-CoA reductase; $\mathrm{BCa}$, breast cancer; BCAC, breast cancer association consortium; UKBB, UK Biobank; IGF-I, insulin-like growth factor 1; IGFBP-3, insulin-like growth factor binding protein 3.

${ }^{\mathrm{a}}$ Associations are per 1 SD unit increase in LDL-C as proxied by genetic variation in HMGCR. 